\title{
GRANICE RZECZYWISTE I SYMBOLICZNE. PRZYPADEK PORTORYKO
}

\author{
BORDERS AND BOUNDARIES, REAL AND SYMBOLIC: \\ THE CASE OF PUERTO RICO
}

\begin{abstract}
The aim of this article is to outline the real and symbolic borders and boundaries, of geographical, political, cultural and racial nature, in the history and present of Puerto Rico, and their role in shaping and transforming the Puerto Rican identity. The main part of the article focuses on the borders and boundaries between Puerto Rico and the United States. The second part looks at the lines dividing the population in the island and the Puerto Rican diaspora in the US.
\end{abstract}

Key words: Puerto Rico; United States; Nuyoricans; diaspora; boundaries; borders; identity

\section{Streszczenie}

Celem artykułu jest zarysowanie rzeczywistych i symbolicznych granic, geograficznych, politycznych, rasowych i kulturowych, wpisujących się w historię i współczesność Portoryko oraz ich roli w kształtowaniu się i przekształcaniu tożsamości portorykańskiej. Gtówna część artykułu skupia się na granicach biegnących między Portoryko a Stanami Zjednoczonymi. W drugiej części wskazano linie podziału powstałe między mieszkańcami wyspy a diasporą portorykańską w USA.

Stowa kluczowe: Portoryko; Stany Zjednoczone; Nuyoricans; diaspora; granica; tożsamość

ANNA KAGANIEC-KAMIEŃSKA Uniwersytet Jagielloński w Krakowie E-mail: a.kaganiec-kamienska@uj.edu.pl https://orcid.org/0000-0002-6260-8789

CITATION: Kaganiec-Kamieńska, A. (2020) Granice rzeczywiste i symboliczne: Przypadek Portoryko. Sprawy Narodowościowe: Seria nowa, 2020(52), Article 2373. https://doi.org/10.11649/sn.2373

This work was supported by the author's own resources. No competing interests have been declared.

This is an Open Access article distributed under the terms of the Creative Commons Attribution 3.0 PL License (creativecommons.org/licenses/by/3.0/pl/), which permits redistribution, commercial and non-commercial, provided that the article is properly cited. (C) The Author(s) 2020

Publisher: Institute of Slavic Studies, Polish Academy of Sciences

Publishing History: Received 2020-08-12; Accepted 2020-12-13; Published 2020-12-23 
stotną perspektywą badawczą w rozważaniach nad Portoryko jest obecnie transnarodowość. To stosunkowo nowe ujęcie (Levitt \& Jaworsky, 2007; Vertovec, 2012) daje możliwość wyjścia poza tradycyjne rozumienie narodów jako ograniczonych przestrzenie sztywnymi granicami. Ich zatarcie i rozmycie pozwala spojrzeć na społeczności jako na wspólnoty dynamiczne i płynne, osadzone w różnych miejscach i poddane różnym wpływom. W taki sposób postrzega Portorykańczyków Jorge Duany (Duany, 2011, s. 17), zdaniem którego „Tożsamości wielu osób w diasporze (...) nie można zawrzeć w obrębie jednego państwa narodowego, a ich praktyk i dyskursów nie da się w pełni zrozumieć z ograniczonej perspektywy politycznej, terytorialnej lub językowej". Portorykańczycy zatem tworzą społeczność transnarodową (Duany, 2002) przekraczającą granice geograficzne i kulturowe, lecz nie polityczne. Są swoistym „transnarodowym narodem”, czyli „społecznością rozszczepioną między dwa miejsca, dwa języki i dwie kultury, ponad fizycznymi i symbolicznymi granicami politycznej suwerenności" (Duany, 2007, s. 121)1.

Temat granic i pogranicza od lat przyciąga uwage badaczy, co znajduje swoje odzwierciedlenie w powstaniu różnych perspektyw teoretycznych oraz problemów definicyjnych (Donnan \& Wilson, 2007; Kearney, 1991). W podstawowym ujęciu granica rozumiana jest jako linia graniczna między państwami, oddzielająca od siebie określone fizycznie terytoria. Granice między grupami czy społecznościami mogą jednak dotyczyć również zjawisk w przestrzeni społecznej i kulturowej. Stanowią zatem wyobrażone, raczej niż fizycznie określone, symboliczne linie demarkacyjne mające wpływ na życie społeczne. Granice etniczne, rasowe i kulturowe oddzielające i odróżniające od siebie różne społeczności stanowią istotny element kształtujący tożsamości grupowe.

Takie właśnie rzeczywiste i symboliczne granice wpisane są w historię i współczesność Portoryko i Portorykańczyków. Szczególne znaczenie w tym kontekście miało przejęcie wyspy przez Stany Zjednoczone w 1898 roku, co otworzyło zupełnie nowy rozdział w jej historii i wyznaczyło granice, jakich dotąd nie doświadczyła. Wcześniej, przez ponad 400 lat Portoryko znajdowało się pod kolonialną kontrolą Hiszpanii, szybko stając się wyspą o ważnym znaczeniu strategicznym, pozostającą jednak poza centrum kolonialnej gospodarki i kultury w Amerykach. Po zakończonej wojnie amerykańsko-hiszpańskiej wyspa przeszła w ręce amerykańskie, a w 1952 roku uzyskała większą autonomię zmieniając status polityczny na państwo stowarzyszone niebędące integralną częścią Stanów Zjednoczonych (hiszp. Estado Libre Asociado, ang. Commonwealth of Puerto Rico). Podobnie jak pod rządami kolonialnymi Hiszpanii, tak i dzisiaj Portoryko lokuje się na obrzeżach, tym razem amerykańskiego, społeczeństwa i polityki, a zdaniem wielu status polityczny wyspy pozostaje zbliżony do kolonialnego. Portorykańczycy są przy tym obywatelami amerykańskimi, dzięki czemu mogą bez przeszkód osiedlać się w USA. Fale migracji i następujące w jej konsekwencji procesy asymilacji i akulturacji do społeczeństwa amerykańskiego prowadziły w efekcie do wykształcenia się różnic pomiędzy mieszkańcami wyspy a diasporą.

Celem artykułu jest zarysowanie rzeczywistych i symbolicznych granic, geograficznych, politycznych, rasowych i kulturowych, wpisujących się w historię i współczesność Portoryko oraz ich roli w kształtowaniu się i przekształcaniu tożsamości portorykańskiej. Główna część artykułu skupia się na granicach biegnących między Portoryko a Stanami Zjednoczonymi. W drugiej wskazano linie podziału powstałe między mieszkańcami wyspy a diasporą portorykańską w USA.

\section{-....}

Porównanie diaspory portorykańskiej, kubańskiej i dominikańskiej w ujęciu transnarodowym zob. Duany 2011. Na temat diaspory kubańskiej zob. też Duany, 2012. Autor ten zwraca uwage na ważną rolę relacji między Stanami Zjednoczonymi a miejscem pochodzenia w kształtowaniu się transnacjonalizmu migrantów. 
Czy geografia ma znaczenie? Wyspa a tożsamość portorykańska

Portoryko, przez miejscowych Indian zwane Boriquen, było jedną z pierwszych wysp odkrytych przez Kolumba w czasie jego podróży do Nowego Świata. Złe traktowanie, przymusowa praca, niedożywienie i epidemie spowodowały, że już w pierwszych dekadach XVI wieku drastycznie zmniejszyła się populacja Indian. Z czasem zostali oni niemal całkowicie wyniszczeni, a w ich miejsce hiszpańscy kolonizatorzy sprowadzali czarnych niewolników (López, 1980).

Wyspa początkowo dostarczała Koronie Hiszpańskiej tak pożądanego przez nią złota, kiedy jednak złoża szybko się wyczerpały, wyspa zaczęła pełnić inną, przede wszystkim strategiczną funkcję - jako "wejście i klucz do wszystkich Indii”, jak w latach 1530. stwierdził gubernator Francisco Manuel de Lando (López, 1980, s. 28). Udoskonalane i rozbudowywane przez dziesiątki lat umocnienia wojskowe skutecznie opierały się atakom Anglików, Francuzów, czy Holendrów w XVI-XVIII wieku.

Portoryko pozostawało na obrzeżach kolonii hiszpańskich nie tylko geograficznie. Pod względem rozwoju demograficznego, społecznego, kulturalnego, intelektualnego i gospodarczego nie mogło się równać z głównymi centrami kolonialnymi - Nową Hiszpanią (Meksykiem) i Peru. Polityka Korony ogólnie nie sprzyjała rozwojowi wyspy. Pewną poprawę sytuacji gospodarczej i społecznej przyniosły reformy burbońskie oraz napływ katolickich imigrantów na przełomie XVIII i XIX wieku. Ostatecznie jednak system plantacyjny na wyspie nie rozwinął się tak znacząco jak na Kubie (López, 1980). W XIX wieku Portoryko pozostało lojalne względem Hiszpanii aż do 1898 roku, na co wpływ miały między innymi obecność wojsk hiszpańskich i napływ rojalistów uchodzących z ogarniętej walkami niepodległościowymi Ameryki hiszpańskiej. Nie oznacza to jednak, że nastroje niepodległościowe były na wyspie całkowicie nieobecne. Wyspa nie posiadała ani tradycji handlu, ani rozwiniętej kultury miejskiej, a wśród ludności istniał wyraźny podział między mieszkańcami stolicy i nielicznych innych miast, a mieszkańcami interioru pogłębiany również przez niewystarczająco rozwinięty system komunikacji (Lewis, 1963). W momencie przejęcia Portoryko przez USA wyspa była stosunkowo rzadko zaludniona, o słabo rozwiniętej infrastrukturze i systemie szkolnictwa, bez własnego uniwersytetu.

Specyfika wyspy i jej położenie geograficzne miały wpływ na ukształtowanie się portorykańskiego charakteru. Takiego zdania był między innymi Antonio Pedreira (Pedreira, 1934/2011), jeden z czołowych intelektualistów tak zwanego Pokolenia 1930 o szczególnych zasługach dla ukształtowania się tożsamości portorykańskiej. W swoim eseju „Insularismo" Pedreira napisał (Pedreira, 1934/2011, ss. 139, 178): „odizolowanie i małe rozmiary geograficzne skazały nas na życie w wiecznym podporządkowaniu”. Jego zdaniem, "ograniczenia natury geograficznej, historycznej i politycznej" skutkowały wykształceniem się u Portorykańczyków kompleksu niższości. Sam Pedreira zalecał otwarcie wyspy się na świat (zob. też Fernández Valledor, 1993).

Zdaniem Gordona K. Lewisa (Lewis, 1963) portorykańscy robotnicy, a szczególnie mieszkający w interiorze rolnicy, odziedziczyli po wczesnych osadnikach cechę "antyspołecznych indywidualistów" (anti-social individualism). Wśród tych osadników znajdowali się marynarze i żołnierze stacjonujący w garnizonie, którzy następnie zamieszkali na górzystych terenach w głębi wyspy. Na przełomie XVIII i XIX wieku hiszpańscy oficjałowie 
postrzegali mieszkańców z interioru jako gnuśnych i nieprzystosowanych. Odległość, w jakiej od siebie mieszkali, miała skutkować brakiem poczucia jedności i tożsamości.

Jíbaro, czyli ubogi rolnik z interioru wiodący rustykalne, proste życie różniące się od stylu życia mieszkańców stolicy i innych miast, jest postacią, w której, jak stwierdziła Teresa Babín (Babín, 2008, s. 79), "konkretyzuje się esencja narodowości portorykańskiej”. Jej zdaniem (Babín, 2008, s. 81), „jibaro reprezentuje w narodowości portorykańskiej to, co najbardziej serdeczne, odporne i czyste". Pedreira (Pedreira, 1934/2011, s. 159) określił go jako "główny korzeń naszej kultury". Z kolei nacjonaliści, jak zauważył Duany (Duany, 2002, s. 19), ustanowili go „romantyczną ikoną czystej portorykańskości”. Idealizowali oni kolonialną rolniczą przeszłość, przeciwstawiając ją amerykańskiemu kapitalizmowi przemysłowemu. A zatem, dla kształtowania tożsamości Portoryko i poczucia jego odmienności od USA ważne było nie tylko położenie wyspy i dystans dzielący ją od Stanów Zjednoczonych, ale także symboliczne przeciwstawienie tego, co reprezentować miała kultura amerykańska i tego, czym bogata jest kultura miejscowa. Niemniej jednak, odizolowanie Portoryko od Stanów Zjednoczonych oraz stosunkowo niewielki napływ Amerykanów na wyspę wymieniane są wśród czynników, które przyczyniły się do niepowodzenia polityki amerykanizacji, prowadzonej tam szczególnie intensywnie w trzech pierwszych dekadach XX wieku. Brak konieczności używania angielskiego jako języka powszechnej komunikacji nie sprzyjał, na przykład, jego upowszechnieniu we wszystkich sferach życia, co pomogło w utrzymaniu silnej pozycji hiszpańskiego.

\section{Granica polityczna.}

Status polityczny wyspy i obywatelstwo amerykańskie

Przed 1917 rokiem Portorykańczycy nie posiadali amerykańskiego obywatelstwa. Foraker Act z 1900 roku określit ich status jako „obywateli Portoryko i jako takich upoważnionych do ochrony Stanów Zjednoczonych" (" citizens of Porto Rico, and as such entitled to the protection of the United States"). Ich status doprecyzowany zostat wyrokiem Sacdu Najwyższego z 1904 roku, który stwierdzał, że Portorykańczycy nie byli cudzoziemcami („aliens”), ale „obywatelami bez obywatelstwa” („noncitizen nationals”), dzięki czemu mogli bez przeszkód podróżować do USA. Obywatelstwo amerykańskie nadał Portorykańczykom Jones Act, jednak sama wyspa nadal pozostała „terytorium” USA (Delgado Cintrón, 2015). Po zmianie statusu politycznego w 1952 roku wyspa uzyskała ograniczoną autonomię, jednak krytycy zwracają uwage na to, że status ten nadal jest zbliżony do koIonialnego. Juan Flores, na przykład, określa Portoryko jako „postkolonialną kolonię” - postcolonial colony (w: Duany, 2002, s. 122). W Kongresie USA wyspa reprezentowana jest przez Komisarza Rezydenta, który może się wypowiadać na forum Kongresu, nie może jednak brać udziału w głosowaniach. Podobnie, mieszkańcy Portoryko nie głosują w amerykańskich wyborach prezydenckich.

Zdaniem Duany'ego (Duany, 2011, s. 103), „Portorykańczycy ilustrują jeden z głównych dylematów podmiotów kolonialnych w ich metropoliach: choć pod względem prawnym są miejscowi (domestic), pod względem kulturowym często są postrzegani jako obcokrajowcy." Doświadczyli tego, na przykład, robotnicy rolni wyjeżdżający do pracy w USA w ramach programu Farm Labor Program zainicjowanego przez rząd portorykański w 1947 roku. Mimo że w 1951 roku Portorykańczyków uznano za "rodzimą siłę roboczą" 
"domestic labor supply", to jednak w kręgach urzędników, pracodawców i dziennikarzy byli oni nadal często uważani za „obcokrajowców”, „pół-obcokrajowców” (semi-foreigners) lub „cudzoziemców” (aliens), głównie ze względu na brak umiejętności posługiwania się angielskim oraz różnice kulturowe (Meléndez, 2017). Obywatelstwa drugiej kategorii krytycy dopatrują się także w fakcie, że po uderzeniu huraganu María we wrześniu 2017 roku pomoc federalna przyszła późno i była niewystarczająca. Zwrócono uwagę, że stany, które w przeszłości doświadczyły zniszczeń na skutek huraganów Katrina lub Rita, uzyskały pomoc federalną znacznie szybciej. Portoryko stanowi zatem „kolonialne peryferie” (Meléndez, 2017, s. 12) i znajduje się na obrzeżu amerykańskiej polityki i społeczeństwa. Meléndez (Meléndez, 2017) twierdzi, że migrację portorykańską do USA należy rozumieć jako "migrację kolonialną", płynącą z nieinkorporowanego, kolonialnego terytorium Stanów Zjednoczonych. Zdaniem Duany'ego (Duany, 2011), migranci z wyspy pod wieloma względami mają więcej wspólnego z migrantami z kolonii niż z krajów niepodległych.

Ogólnie jednak większość Portorykańczyków nie widzi sprzeczności między portorykańską narodowością a amerykańskim obywatelstwem (Duany, 2002). Jak pokazały badania Nancy Morris (Morris, 1995), dumę z Portoryko i bycia Portorykańczykami odczuwają również ci, którzy opowiadają się za inkorporacją wyspy do USA (pro-statehood).

Po 1952 roku w Portoryko przeprowadzono kilka plebiscytów w sprawie statusu politycznego wyspy. Wykazały one, że idea niezależności cieszy się niewielkim poparciem. Jednocześnie jednak w większości plebiscytów Portorykańczycy nie zagłosowali też za przyłączeniem do Stanów Zjednoczonych (statehood), zaznaczając tym samym symboliczną granice pomiędzy wyspą a USA. Opowiedzieli się za tym, przynajmniej teoretycznie, dopiero w 2012 i 2017 roku, jednak wyniki tych referendów były podważane i szeroko komentowane. Ponadto, głosowanie w 2017 roku zbojkotowała duża część społeczeństwa, co bezsprzecznie zaważyło na ostatecznym wyniku (Kaganiec-Kamieńska, 2019).

\section{Granica kulturowa i jezzkowa}

Kultura wyspy ukształtowała się w oparciu o trzy główne korzenie: hiszpańskich kolonizatorów, ludność tubylczą i czarnoskórych niewolników. Jej rozwój wsparły następnie grupy imigrantów przybywających głównie w XVIII i XIX wieku. Kiedy w 1898 roku Portoryko trafiło $w$ ręce amerykańskie, wyspa różniła się wyraźnie pod względem kulturowym od anglosaskiej u swego zarania, protestanckiej, imigranckiej, a więc zróżnicowanej rasowo i etnicznie, Ameryki. Kolejne fale przybyszów, napływające do Stanów Zjednoczonych w XX wieku, wniosły dalszy wkład w rozwój kultury amerykańskiej, odmiennej od hiszpańsko-karaibskiej kultury portorykańskiej (Daniels, 2002).

Przejęcie wyspy przez Amerykanów oznaczało nie tylko zmiany polityczne i gospodarcze. W przestrzeni miejskiej stolicy dokonywały się przeobrażenia. Amerykanie starali się uczynić z San Juan „okno wystawowe” amerykańskiej kultury i stylu życia oraz nadać stolicy rys nowoczesności. Oblicze miasta zmieniały nowe budynki szkół, banków i kościołów wyznań dotychczas nieobecnych na jak dotąd katolickiej wyspie. Reprezentacyjną ulicą stał się nowy bulwar, dawna droga wojskowa Carretera Militar, przy którym pojawiły się eleganckie budynki ważnych instytucji rządowych i kulturalnych takich jak Kapitol, Biblioteka Carnegie, czy Casa España, jak również hotele i parki (Pabón-Charneco, 2017). Rozwijała się infrastruktura transportowa. 
Głównym narzędziem amerykanizacji mieszkańców wyspy były jednak język angielski i system szkolnictwa. Polityka amerykanizacji miała upowszechnić amerykańskie idee i wartości oraz przygotować Portoryko na jego inkorporację do USA. W 1902 roku legislatura ustanowiła dwa języki oficjalne - hiszpański i angielski. Nauczanie w publicznych szkołach podstawowych aż do 1948 roku odbywało się wyłącznie lub częściowo po angielsku, a w szkołach średnich wyłącznie po angielsku (Torres González, 2002). Prowadzono też intensywne nauczanie historii USA i starano się wykształcić w dzieciach lojalność wobec tego kraju. Jak stwierdził Luis Muñiz-Argüelles (Muñiz-Argüelles, 1988, s. 461), „dzieci portorykańskie znały historię USA lepiej niż ich koledzy w Stanach Zjednoczonych".

Portorykańczycy oparli się jednak amerykanizacji i narzuceniu języka angielskiego (DeIgado Cintrón, 2015; Torres González, 2002). Język hiszpański stał się jednym z głównych elementów „portorykańskości”, a angielski skojarzono z amerykańskim imperializmem. Również dzisiaj, jak pokazują badania Eisenstein Ebsworth i in. (Eisenstein Ebsworth i in., 2018, s. 76), niektórzy Portorykańczycy uważają, że „,historia nauczania języka angielskiego na wyspie ma ważny wpływ na jego przyswajanie". Wiązane jest to właśnie z amerykańskim kolonializmem, a także z licznymi zmianami w polityce nauczania obu języków wprowadzanymi na przestrzeni wielu dekad.

Po zmianie statusu politycznego wyspy w 1952 roku lokalny rząd prowadził politykę rozwoju i ochrony kultury i tożsamości portorykańskiej (Cruz Santos, 2014). Pierwszy gubernator wybrany w powszechnych wyborach, Luis Muñoz Marín (1948-64), uważat, że polityczne stowarzyszenie z USA nie wyklucza rozwoju tożsamości portorykańskiej. Głoszono autonomię duchową narodu portorykańskiego, promowano wizję Portoryko jako harmonijnego połączenia trzech ras - białej, indiańskiej i afrykańskiej. Prowadzono badania etnograficzne i archeologiczne, promowano lokalne zwyczaje i ikony, takie jak jibaro. Ideologię nacjonalizmu kulturowego wspomagał między innymi powołany w tym okresie Instytut Kultury Portorykańskiej (Cruz Santos, 2014; Duany, 2002). Oficjalnie przyjęto i rozpropagowano symbole narodowe, które są silnie osadzone w historii wyspy. Godłem Portoryko (w obecnej wersji zatwierdzone w 1976 r.), na przykład, zostało godło nadane wyspie już w 1511 roku przez Królów hiszpańskich. Jest ono obecnie najstarszym w Amerykach godłem pozostającym nadal w użyciu.

Mimo że od 1968 roku Portoryko promuje politykę dwujęzyczności, obecna sytuacja językowa na wyspie przedstawia sobą skomplikowany obraz. Głównym językiem mieszkańców i językiem narodowym jest hiszpański, a język angielski symbolizuje prestiż społeczno-ekonomiczny. W sądownictwie federalnym funkcjonuje angielski, natomiast w sądach lokalnych - hiszpański, co zostało potwierdzone wyrokiem Sądu Najwyższego Portoryko z 1965 roku (Delgado Cintrón, 2015; Pousada, 2008). Nacisk na język angielski kładą szkoły prywatne, które często używają go jako języka wykładowego. Ogólnie jednak, pomimo dwóch języków oficjalnych i wdrażanych polityk językowych, Portoryko nie jest w pełni dwujęzyczne.

Istniejąca między Stanami Zjednoczonymi a Portoryko granica kulturowa i językowa jest, zdaniem wielu, przeszkodą uniemożliwiającą inkorporację wyspy do USA. Z kolei dla osób wyjeżdżających do USA słaba znajomość angielskiego lub jej brak pozostaje często poważną przeszkodą utrudniającą przystosowanie do nowej rzeczywistości na kontynencie. W ostatnich latach problem ten odnotowano na przykład wśród migrantów opuszczających wyspę po huraganie María, w tym, co istotne, również wśród młodzieży zapisywanej do szkół w nowym miejscu pobytu na Florydzie (Meléndez i in., 2017). 
Portoryko trafiło pod kontrolę amerykańską w okresie, gdy w USA obecne były idee natywistyczne i przekonanie o wyższości rasy białej. Koniec XIX i pierwsze dekady XX wieku naznaczone były segregacją i dyskryminacją rasową, a na amerykańskim Południu rozpowszechnione były prawa Jima Crowa. Zgodnie z tą logiką, Amerykanie postrzegali Portorykańczyków jako zacofanych i nieprzygotowanych do samorządzenia, rasowo i kulturowo niższych od posiadających anglosaskie korzenie Amerykanów (Duany, 2002).

Pod względem stosunków międzyrasowych Portoryko znacząco różniło się od Stanów Zjednoczonych. Wielu widziało w wyspie „demokracje rasową”, w której akceptowano mieszanki rasowe, a dyskryminacja i uprzedzenia były mniej wyraźne (Duany, 2002). Podczas gdy na wyspie nierzadkie były związki międzyrasowe, a jaśniejszych mulatów akceptowano jako białych (Alleyne, 2005), w USA rasową przynależność determinowała najmniejsza nawet domieszka „czarnej krwi” (one-drop rule), a w niektórych stanach międzyrasowe związki małżeńskie były zabronione aż do 1967 roku.

Różnice między Portoryko i Wyspami Dziewiczymi a Stanami Zjednoczonymi opisał na przykład Eric Williams (Williams, 1945). Zwrócit on uwagę na brak segregacji rasowej oraz równość w sferze politycznej. Uważał on, że brak dyskryminacji na poziomie prawnym wynikał z faktu, że różnice rasowe były na wyspie podrzędne względem różnic klasowych, a mobilność mulatów na drabinie społecznej łatwiejsza niż w USA. Skontrastował on „brak dyskryminacji” w Portoryko i na Wyspach Dziewiczych z trendem w USA zmierzającym w strone „większej dyskryminacji”. Zwrócił też uwage na pozytywne działania, jakie w sferze stosunków rasowych podejmował przyszły gubernator Luis Muñoz Marín oraz jego partia polityczna. Nie oznacza to jednak, że na wyspie nie istniały problemy rasowe, na co Williams zwrócit uwage wskazując dyskryminację w szkołach prywatnych i uprzedzenia, które w sferze społecznej miały być obecne jeszcze przed przybyciem Amerykanów. Inne zdanie na temat uprzedzeń miał z kolei portorykański pisarz Tomás Blanco, który uważat, że to Amerykanie byli źródłem uprzedzeń rasowych na wyspie i to od nich przejęli je Portorykańczycy (Fernández Valledor, 1993).

Początków luźniejszych niż w USA stosunków rasowych na wyspie należy szukać się w okresie kolonialnym. W czasach hiszpańskich interakcje między różnymi grupami rasowymi w Portoryko były prawdopodobnie dość swobodne, a stosunki między nimi bardziej płynne (Alleyne, 2005), choć historia wyspy nie była wolna była od przemocy, uprzedzeń, stereotypów, dyskryminacji i systemu kastowego (Alleyne, 2005; López, 1980). Stosunki międzyrasowe ułatwiał funkcjonujący na wyspie system gospodarczy. Ponieważ nie wykształciły się tutaj wielkie plantacje, liczba przywożonych niewolników była znacznie niższa niż na innych wyspach karaibskich. W odróżnieniu do kolonii brytyjskich, w Portoryko wykształciła się też duża grupa „wolnych kolorowych”, którzy uzyskali wolność od swoich panów lub wykupili się samodzielnie. W efekcie, w przeddzień zniesienia niewolnictwa (1873) niewolnicy stanowili jedynie 5\% ludności (Alleyne, 2005). Ponadto, istniała tu również grupa białych pracowników kontraktowych.

Zdaniem Alleyne (Alleyne, 2005) bliskie relacje między różnymi grupami rasowymi dały w efekcie stosunkowo homogeniczną kulturę portorykańską. Obok elementów afrykańskich, ważną rolę odgrywają tutaj korzenie indiańskie, a boricuismo (termin wywodzący się od oryginalnej nazwy wyspy w języku Indian Taíno) jest dla portorykańskości równie istotne, co jíbarismo (Babín, 2008). 
Inaczej niż Amerykanie, większość Portorykańczyków nie wiąże rasy jedynie z pochodzeniem (descent). Jak wyjaśnia Duany (Duany, 2002, s. 245): „w rezultacie, osoba o mieszanym pochodzeniu rasowym nie jest automatycznie przypisywana do grupy czarnoskórej w Portoryko. Klasyfikacja rasowa w przeważającym stopniu zależy raczej od koloru skóry i innych widocznych cech, takich jak kształt ust i nosa oraz tekstura włosa. Znaczenie ma również status społeczny (włączając w to dochód, zawód i wykształcenie)" (zob. też Alleyne, 2005; Rodríguez, 2000).

W społeczeństwie nadal funkcjonuje wiele określeń wyłamujących się ze sztywnych kategorii rasowych narzucanych przez amerykański spis powszechny (Alleyne, 2005; Duany, 2002). O tym, że używane przez Amerykanów kategorie nie wydają się adekwatne dla opisu portorykańskiej rzeczywistości świadczy na przykład to, że w 1960 roku z formularza spisu powszechnego na wyspie usunięto pytanie o rasę i przywrócono je dopiero w 2000 roku (Duany, 2005).

Co ciekawe, w spisie powszechnym mieszkańcy wyspy identyfikują się obecnie w znacznej większości jako przedstawiciele rasy białej (75,8\% w 2010 r.) (U.S. Census Bureau, 2020). Stoi w kontraście z danymi demograficznymi z czasów kolonii hiszpańskiej, z których wynika, że Portorykańczycy byli społeczeństwem bardziej zróżnicowanym rasowo. Odsetek „białych” Portorykańczyków wzrósł w XIX wieku, a w przeddzień przejęcia wyspy przez USA osiągnął 64\%. Dalszy proces „wybielania” wyspy nastąpit po 1898 roku. Istnieje kilka interpretacji tego procesu (Duany, 2005), wydaje się jednak, że duże znaczenie miało zderzenie się ze sobą portorykańskiego i amerykańskiego sposobu rozumienia i klasyfikowania rasy. Amerykański spis powszechny narzucał binarny podział na ludność "rasy białej” i tych, którzy biali nie byli, podczas gdy na wyspie dostrzegano różnice pomiędzy grupami. Zdaniem Duany'ego (Duany, 2005, s. 178), fakt, że U.S. Census zrezygnował ze stosowania w spisach powszechnych kategorii pośrednich (takich jak Mulat), „na wyspie przyspieszył przejście z kategorii nie-białych do białych”.

Identyfikacja rasowa diaspory w Stanach Zjednoczonych różni się od tej na wyspie. Do 1970 roku U.S. Census Bureau klasyfikował Portorykańczyków w USA z reguły jako "białych" (white), „chyba że zdecydowanie byli czarnoskórzy, Indianami lub innej rasy". W 1980 roku do formularza spisowego wprowadzono dwa odrębne pytania o autoidentyfikację, a mianowicie, o identyfikację rasową oraz pochodzenie etniczne Hispanic²; po raz pierwszy wprowadzono też ankiety wypełniane samodzielnie przez respondentów (Rodríguez, 2000). Zmiany te w efekcie pokazały, że sami Portorykańczycy w USA równie często identyfikują się jako „,biali”, jak i „innej rasy” (other race). W 2000 roku odsetek ten wyniósł odpowiednio 46,4 i 45,8\% (Duany, 2005). Zdaniem Duany'ego (Duany, 2005, s. 182) funkcjonująca w amerykańskim spisie kategoria rasowa „inna rasa” "wydaje się być coraz częściej używana jako urasowiony (racialized) synonim określenia Hispanic. (...) Wielu Portorykańczyków woli nie określać siebie ani jako biały, ani jako czarny, jeśli mają inną opcję przypuszczalnie wskazującą mieszane pochodzenie". Z kolei badania przeprowadzone przez Clarę Rodríguez pokazały, że większość respondentów określiła się jako „innej rasy” ze względu na „ich kulturę, rodzinę, miejsce urodzenia, proces socjalizacji lub polityczne poglądy", nie zaś ze względu na (mieszaną) charakterystykę rasową (Duany, 2005). Identyfikacja rasowa Portorykańczyków w USA stanowi zatem interesujący pro-

\footnotetext{
2 "Race" and „Hispanic origin” - Hispanics należą zatem do tej samej kategorii etnicznej, ale mogą być różnych ras (", of any race").
} 
blem badawczy. Co ciekawe, w 2010 roku odsetek „białych” Portorykańczyków wzrósł do 53,1\%, a „innej rasy” spadł do 27,8\% (Ennís i in., 2011, s. 14). Być może można to tłumaczyć dużą falą migracyjną z wyspy.

\section{CZY TO TEŻ "MY"? ZIEMIA, JEZZYK I KULTURA. PORTORYKAŃCZYCY A DIASPORA PORTORYKAŃSKA W USA}

Dekady migracji oraz następujących w jej konsekwencji procesów asymilacji i akulturacji do społeczeństwa amerykańskiego prowadziły do wykształcenia się różnic pomiędzy mieszkańcami wyspy a diasporą.

Czynnikiem stymulującym migrację do USA była i jest perspektywa znalezienia pracy oraz poprawy sytuacji życiowej. Szczególnie liczna fala, określana jako Wielka Migracja, popłynęła do Stanów Zjednoczonych w latach 1945-1965, przy czym w samej tylko dekadzie lat 50. wyjechało aż 470000 osób kierujących się głównie do Nowego Jorku będącego wówczas głównym miejscem docelowym migrantów. W dekadzie lat 1970. i 80. Portoryko odnotowało znaczące fale migracji powrotnych. Ostatecznie migracja przyjęła postać wahadłową (revolving-door), a migranci rozproszyli się również poza Nowy Jork (Duany, 2007). W tym kontekście Duany (Duany, 2011) mówi o fazie migracji „post-nuyorican". Obecnie liczba osób o pochodzeniu portorykańskim w USA przewyższa populację wyspy i stale rośnie. Według danych spisowych w 2010 roku diaspora liczyła 4600000 osób (podczas gdy populacja Portoryko wynosiła 3700 000), a według szacunków z 2016 roku - 5500000 osób (Ennís i in., 2011). W ostatnich latach liczba wyjeżdżających z wyspy nie maleje, na co wpływ ma dotkliwy kryzys gospodarczy na wyspie oraz zniszczenia po przejściu huraganu María.

\section{Portoryko wobec diaspory. Nuyoricans wobec portorykańskości}

Do lat 1960. w USA dominowało przekonanie o konieczności całkowitej asymilacji grup mniejszościowych do amerykańskiego społeczeństwa. Jednak w 1964 roku amerykański socjolog Milton Gordon wyróżnił siedem typów asymilacji ${ }^{3}$, w tym akulturację, czyli asymilację kulturową. Gordon (Gordon, 1964) zastosował swój model do analizy czterech grup etnicznych: czarnoskórych, Żydów, katolików i właśnie Portorykańczyków. Porównanie efektów akulturacji w grupie czarnoskórych (jednej z najstarszych grup mniejszościowych w USA) i Portorykańczyków (najmłodszej licznej grupy migrantów) pozwoliło mu sformułować ważne wnioski. Jego zdaniem (Gordon, 1964, s. 77), akulturacja stanowi „przypuszczalnie pierwszy” typ asymilacji, jaki zachodzi w grupach mniejszościowych. Co więcej, jak zauważył, może być ona jedyną fazą asymilacji, jaka nastąpi. Oznacza to, że osoby akulturowane do społeczeństwa amerykańskiego mogą nadal, przykładowo, mieszkać w swoich społecznościach etnicznych, wchodzić w związki małżeńskie z osobami ze swojej grupy etnicznej, i niekoniecznie asymilować się w innych wymiarach.

3 Asymilacja strukturalna, amalgamacyjna, identyfikacyjna, osobowościowa, behawioralna, obywatelska oraz akulturacja. 
To właśnie mniej więcej w latach 1960. członkowie diaspory zaczęli postrzegać siebie jako mniejszość etniczną (Sánchez, 2007). W pierwszej paradzie Puerto Rican Day Parade w Nowym Jorku w 1958 r. wzięło udział 30 tysięcy osób, a w święcie Jana Chrzciciela ${ }^{4}$ w 1964 roku - 60 000. W 1965 roku w Central Parku po raz pierwszy odbył się Puerto Rican Folk Festival (Duany, 2002). W latach 60. i 70. powstało też w Nowym Jorku wiele instytucji i grup, takich jak Museo del Barrio (1969), Taller Boricua (1971), czy Nuyorican Poets Café (1973), które służyły członkom społeczności, również jako miejsce ekspresji ich tożsamości. Równocześnie, Portorykańczycy zaangażowali się w amerykański ruch o prawa obywatelskie.

Do końca lat 1960. lokalny rząd portorykański traktował członków diaspory jako „migrujących obywateli" (migrant citizens), którzy wymagali pomocy w organizacji wyjazdu, jak również w przystosowaniu i adaptacji do rzeczywistości amerykańskiej. Aktywnym wsparciem migrantom służył w tym okresie między innymi Migration Division w Nowym Jorku, współpracujący z powstającymi w USA licznymi organizacjami i klubami portorykańskimi, w tym hometown clubs (Duany, 2002; Meléndez, 2017). Po 1968 roku rządzący wyspą dostrzegli, że Portorykańczycy nie stanowią monolitu, ale społeczność złożoną z dwóch części - tej mieszkającej na wyspie oraz tej w USA. Zmiana nastawienia wobec diaspory skutkowała podjęciem inicjatyw promujących kulturę portorykańską. Organizowano wystawy i wykłady, współpracowano z nowojorskim Museo del Barrio, a także wspierano organizacje parad czy świąt (Duany, 2002).

Migracja oraz wyłanianie się diaspory portorykańskiej w USA były, zdaniem wielu, zagrożeniem dla utrzymania portorykańskiej tożsamości i potencjalnym źródłem zanieczyszczenia kultury Portoryko. W Nuyoricans widziano osoby przechodzące kryzys tożsamości na skutek utraty korzeni kulturowych (Duany, 2002). Również i dzisiaj Portorykańczycy nie zawsze przychylnie patrzą na Nuyoricans i przyjmują ich czasem dość chłodno, widząc w nich odmiennych "strangers" i zarzucając im zdradę autentycznej kultury portorykańskiej. Portorykańczycy postrzegają powracających na wyspę Nuyoricans jako „innych", niepotrafiących się zaadaptować i często trzymających się "swojej" grupy (Morris, 1995). Chcą też się odciąć od negatywnych stereotypów przypisywanych Nuyoricans (Verin-Shapiro, 2000). Portorykańczycy mają też uważać ich za „bardziej agresywnych, nieokazujących szacunku i rozwiązłych od siebie". Z kolei sami Nuyoricans uważają siebie za „bardziej kosmopolitycznych i wyrafinowanych od Portorykańczyków” (Duany, 2011, s. 74).

Migranci powrotni na wyspie spotykają się z negatywnymi reakcjami ze strony mieszkańców również ze względów językowych (Morris, 1995; Zentella, 1990). Badania Any Celii Zentelli (Zentella, 1990) pokazały, że przebywający na wyspie Nuyoricans wiązali wrogość, jakiej doświadczali ze strony Portorykańczyków z klasy niższej i nastolatków z zawiścią wynikającą z ich znajomości angielskiego. Sama obecność migrantów powrotnych ma z kolei wpływ na sytuację językową na wyspie. Są oni jedną z czterech zidentyfikowanych przez Alicię Pousade (Pousada, 2009) grup osób posługujących się angielskim i drugą, obok Portorykańczyków z klasy średniej i wyższej wykształconych najczęściej w prywatnych szkołach, grupą osób dwujęzycznych.

Język jest de facto jednym z elementów, które komplikują relacje pomiędzy obiema grupami. Tworzy on swoistą „etniczną granicę” (Clachar, 1997, s. 109), na którą zwrócono uwage już kilka dekad temu. Przykładowo, w połowie lat 1970. portorykański antropolog

4 Od jego imienia pochodziła pierwsza nazwa wyspy, San Juan Bautista. 
Eduardo Seda Bonilla odmówił osobom nieposługującym się językiem hiszpańskim prawa do tego, by określali się jako Portorykańczycy. Użył on w tym kontekście określenia „pseudo-etniczność" (Zentella, 1990, s. 86).

\section{Czym jest „portorykańskość”?}

W latach 1970. badacze z Centro de Estudios Puertorriqueños na City University of New York zaczęli podważać dotychczasowy kanon kultury portorykańskiej. Nie zgadzano się z definiowaniem Portorykańczyków na podstawie takich elementów jak terytorium i język (Duany, 2002). O ile zatem język hiszpański na wyspie jest nadal tradycyjnie ważnym elementem tożsamości portorykańskiej, o tyle dla Nuyoricans znajomość hiszpańskiego nie jest warunkiem koniecznym, by czuć się i identyfikować jako Portorykańczyk. Potwierdziły to, na przykład, badania przeprowadzone w 1980 roku wśród Nuyoricans ze Wschodniego Harlemu oraz w 1983 roku w grupie dwujęzycznych uczniów migrantów na wyspie. W pierwszym przypadku aż 80\%, a w drugim $61 \%$ respondentów nie uważało hiszpańskiego za niezbędny element tożsamości portorykańskiej (Zentella, 1990). Ponadto, 90\% respondentów studium z 1983 roku uważało, że osoby posługujące się wyłącznie językiem angielskim mogą być Portorykańczykami. Co ciekawe, prowadzone w ostatnich latach badania zdają się sugerować, że sami Portorykańczycy zaczynają stawiać pod znakiem zapytania związek między tożsamością portorykańską a językiem hiszpańskim (Domínguez Rosado, 2012).

Z tym, że miejsce urodzenia determinuje przynależność do Boricuas nie zgadza się na przykład urodzona w USA często cytowana poetka María Teresa "Mariposa" Fernández". Niezwykle sugestywnie ujęła to w następujących słowach: „Duma z bycia Boricua nie ma nic wspólnego z geografią... Jesteśmy tak samo portorykańscy, jak Portorykańczyk urodzony na wyspie. Bycie Boricua to stan umysłu i stan serca, i stan duszy. I jeśli o mnie chodzi, to jedyny stan, jaki się liczy" (cyt. za: Duany, 2007, s. 120)6.

Słowa "Mariposy" są tym bardziej interesujące, że mogą zawierać grę słów - słowo "stan" może odnosić się bowiem zarówno do nastroju, jak i amerykańskiej jednostki administracyjnej. Jej wypowiedź może zatem być też odczytana jako swoisty komentarz do statusu politycznego wyspy i jego wpływu na identyfikację Portorykańczyków.

W diasporze portorykańskość celebrowana jest na różne sposoby, zarówno formalne, jak i nieformalne, dostosowane do amerykańskiej rzeczywistości i warunków. Nyuoricans eksponują symbole narodowe, obchodzą święta portorykańskie. Codzienne świętowanie portorykańskości przyjmuje postać grona przyjaciół, miejsca zamieszkania, tradycyjnych, popularnych posiłków, czy zakupów w portorykańskich sklepach spożywczych (bodegas). Nuyoricans dopingują sportowców reprezentujących Portoryko i cieszą się z sukcesów portorykańskich kandydatek do tytułów królowej piękności (Duany, 2002).

5 Zob. też jej wiersz „Ode to the DiaspoRican”.

6 El orgullo de ser boricua no tiene nada que ver con la geografía... Somos tan puertorriqueños como el puertorriqueño nacido en la Isla. Ser boricua es un estado de la mente, un estado del corazón y un estado del alma. Y en lo que a mí respecta, ése es el único tipo de estado que cuenta. 
Niewątpliwie, granice (rzeczywiste i symboliczne) między Portoryko i Stanami Zjednoczonymi miały istotne znaczenie dla ukształtowania się tożsamości portorykańskiej, a linie podziału zarysowujące się w obrębie społeczności Portorykańczyków w wyniku procesów migracyjnych przyczynity się do jej reinterpretacji.

Geograficzna izolacja wyspy, ale przede wszystkim opór wobec amerykanizacji po 1898 r. pomogły uformować się tożsamości Portorykańczyków jako społeczności odrębnej i odmiennej od USA, posiadającej własną kulturę wyrosłą na bazie dziedzictwa hiszpańskiego, indiańskiego i afrykańskiego. Występując przeciwko amerykańskiej polityce kulturowej Portoryko skutecznie obroniło też język hiszpański jako język narodowy.

Zależny status polityczny wyspy nie osłabił tożsamości kulturowej Portorykańczyków. $\mathrm{Na}$ uwage zasługuje to, że większość z nich nie widzi sprzeczności między obywatelstwem amerykańskim a narodowością portorykańską. Również i fakt, że Portorykańczycy w USA nie mogą się oddać głosu w przeprowadzanych na wyspie plebiscytach dotyczących jej statusu politycznego nie wydaje się wpływać na ich poczucie przynależności do społeczności portorykańskiej.

W spisach powszechnych Portoryko wpasowuje się w narzucaną przez U.S. Census klasyfikację rasową, równocześnie jednak na co dzień się jej opiera i zachowuje swoją wielorasową tożsamość. Chociaż w formularzu spisowym mieszkańcy wyspy identyfikują się przede wszystkim jako rasowo "biali”, to jednak w ogólnym użyciu pozostaje paleta pośrednich określeń rasowych. Wybór "białej” identyfikacji rasowej może odzwierciedlać zakorzenioną tutaj obawe przed uprzedzeniami rasowymi. W diasporze różnice między Portorykańczykami a Amerykanami wydają się nie tracić na znaczeniu, a identyfikowanie się jako osoba „innej rasy” może być formą zaakcentowania ich hiszpańsko-latynoamerykańskich korzeni kulturowych i rasowych.

Chociaż migracje początkowo interpretowane były jako zagrożenie dla kultury i tożsamości Portorykańczyków, ostatecznie jednak przyczyniły się do reinterpretacji tożsamości grupy. Nuyoricans bronią swojej tożsamości jako Portorykańczyków, a większość członków diaspory określa się jako „Puerto Ricans”. Migracje transnarodowe nie wydają się więc wywierać negatywnego wpływu na identyfikację i poczucie przynależności do narodu portorykańskiego. Interpretacja Jorge Duany'ego (Duany, 2002, 2011) traktująca Portorykańczyków jako „społeczność transnarodową" i "naród w ruchu” doskonale zatem oddaje płynność i hybrydyczność jej tożsamości.

\section{BIBLIOGRAFIA}

Alleyne, M. C. (2005). The construction and representation of race and ethnicity in the Caribbean and the world. University of the West Indies Press.

Babín, M. T. (2008). La Cultura de Puerto Rico. CEAPRC.

Clachar, A. (1997). Ethnolinguistic identity and Spanish proficiency in a paradoxical situation: The case of Puerto Rican return migrants. Journal of Multilingual and Multicultural Development, 18(2), 107-124. https://doi.org/10.1080/01434639708666307

Cruz Santos, M. (2014). Afirmando la nación... Políticas culturales en Puerto Rico (19491968). Ediciones Callejón. 
Daniels, R. (2002). Coming to America: A history of immigration and ethnicity in American life. Perennial.

Delgado Cintrón, C. (2015). Imperialismo jurídico norteamericano en Puerto Rico (18982015). Publicaciones Gaviota.

Domínguez Rosado, B. (2012). Language and identity: The study of a possible ongoing change in attitudes towards American English and Puerto Rican Spanish in Puerto Rico [Niepublikowana rozprawa doktorska]. Universidad de Puerto Rico-Río Piedras.

Donnan, H., \& Wilson, T. M. (2007). Granice tożsamości, narodu, państwa (M. Głowacka-Grajper, Tłum.). Wydawnictwo Uniwersytetu Jagiellońskiego.

Duany, J. (2002). Puerto Rican nation on the move: Identities on the island and in the United States. The University of North Carolina Press.

Duany, J. (2005). Neither white nor black: The representation of racial identity among Puerto Ricans on the island and in the U.S. mainland. W A. Dzidzienyo \& S. Oboler (Red.), Neither enemies nor friends: Latinos, Blacks, Afro-Latinos (ss. 173-188). Palgrave Macmillan. https://doi.org/10.1057/9781403982636_9

Duany, J. (2007). La nación en la diáspora: Las múltiples repercusiones de la emigración puertorriqueña a Estados Unidos. Revista de Ciencias Sociales, 17, 118-153.

Duany, J. (2011). Blurred borders: Transnational migration between the Hispanic Caribbean and the United States. The University of North Caroline Press. https://doi. org/10.5149/9780807869376_duany

Duany, J. (2012). Rozmyte granice: Diaspora kubańska w kontekście hiszpańskich Karaibów. Ameryka Łacińska, 2(76), 74-83.

Eisenstein Ebsworth, M., Ebsworth, T. J., \& Cai, C. (2018). English acquisition in Puerto Rico: Teachers' insights. Bilingual Research Journal, 41(1), 69-88. https://doi.org/10.10 80/15235882.2017.1413441

Ennís, S. R., Ríos-Vargas, M., \& Albert, N. G. (2011). The Hispanic population: 2010. U.S. Census.

Fernández Valledor, R. (1993). Identidad nacional y sociedad en la ensayistica cubana y puertorriqueña, 1920-1940. CEAPRC.

Gordon, M. (1964). Assimilation in the American life. Oxford University Press.

Kaganiec-Kamieńska, A. (2019). Nacjonalizm polityczny i kulturowy w Portoryko a status polityczny wyspy. W J. Kurczewska \& Z. Mach (Red.; z M. Ślarzyńskim), Kultury narodowe i lokalne a polityka: Powiązania w różnych kontekstach (ss. 449-473). Wydawnictwo Instytutu Filozofii i Socjologii Polskiej Akademii Nauk.

Kearney, M. (1991). Borders and boundaries of state and self at the end of empire. Journal of Historical Sociology, 4(1), 52-74. https://doi.org/10.1111/j.1467-6443.1991.tb00116.x

Levitt, P., \& Jaworsky, B. N. (2007). Transnational migration studies: Past developments and future trends. Annual Review of Sociology, 33, 129-156. https://doi.org/10.1146/ annurev.soc.33.040406.131816

Lewis, G. K. (1963). Puerto Rico: Freedom and power in the Caribbean. Harper \& Row Publishers.

López, A. (1980). The Puerto Ricans: Their history, future, and society. Schenkman Publishing Company.

Meléndez, E. (2017). Sponsored migration: The state and Puerto Rican postwar migration to the United States. The Ohio State University Press. https://doi.org/10.2307/j. ctv3znx2t

Meléndez, E., Hinojosa, J., \& Roman, N. (2017). Post-hurricane Maria exodus from Puerto Rico and school enrollment in Florida (Centro Report RB2017-02). Center for Puerto 
Rican Studies. https://centropr.hunter.cuny.edu/sites/default/files/CentroReport-RB2017-02-POST-MARIA-FL-PR-EXODUS\%20\%281\%29.pdf

Morris, N. (1995). Puerto Rico: Culture, politics, and identity. Praeger.

Muñiz-Argüelles, L. (1988). The status of languages in Puerto Rico. Forum, 4(2), 457-472. http://muniz-arguelles.com/articulos.html

Pabón-Charneco, A. (2017). The architecture of San Juan de Puerto Rico: Five centuries of urban and architectural experimentation. Routledge. https://doi. org/10.4324/9781315689258

Pedreira, A. S. (2011). Insularismo: Ensayos de interpretación puertorriqueña. Editorial Plaza Mayor. (1. wyd. 1934).

Pousada, A. (2008). The mandatory use of English in the Federal Court of Puerto Rico. CENTRO Journal, 20(1), 137-155.

Pousada, A. (2009). Dónde están los bilingües? La cartografía del idioma en Puerto Rico [Referat]. "8va Conferencia de la Asociación de Estudios Puertorriqueños", 1-4.10.2008, Centro de Estudios Avanzados de Puerto Rico y el Caribe, San Juan. https://aliciapousada.weebly.com/uploads/1/0/0/2/10020146/prsa_paper-3.pdf

Rodríguez, C. E. (2000). Changing race: Latinos, the census, and the history of ethnicity in the United States. New York University Press.

Sánchez, J. R. (2007). Boricua power: A political history of Puerto Ricans in the United States. New York University Press.

Torres González, R. (2002). Idioma, bilingüismo y nacionalidad: La presencia del inglés en Puerto Rico. Editorial de la Universidad de Puerto Rico.

U.S. Census Bureau. (2020). American FactFinder. https://factfinder.census.gov/

Verin-Shapiro, P. (2000). Why 'Nuyoricans' are given the cold-shoulder by other Puerto Ricans. National Institute of Mental Health, Rockville.

Vertovec, S. (2012). Transnarodowość (I. Kołbon, Tłum.). Wydawnictwo Uniwersytetu Jagiellońskiego.

Williams, E. (1945). Race relations in Puerto Rico and the Virgin Islands. Foreign Affairs, 23(2), 308-317. https://doi.org/10.2307/20029896

Zentella, A. C. (1990). Returned migration, language, and identity: Puerto Rican bilinguals in dos worlds/two mundos. International Journal of the Sociology of Language, 1990(84), 81-100. https://doi.org/10.1515/ijsl.1990.84.81 